\title{
Spazi digitali e modelli immersivi: applicazioni di prospettiva cubica
}

\author{
Adriana Rossi \\ Lucas Fabian Olivero \\ António Bandeira Araújo
}

Abstract

Applicazioni di difficoltà crescente mirano a valutare l'acquisizione delle regole di prospettiva cubica precedentemente elaborate. Gli ambienti costruiti con questo metodo sono stati resi immersivi con l'ausilio di software dedicati. L'operatore è virtualmente proiettato al centro di uno spazio ideale è quindi libero di visualizzare l'interno per analizzare gli aspetti rappresentati. L'esperienza permette allo studioso di auto-correggere gli errori di discontinuità commessi nell'esecuzione piana resi evidenti nella simulazione virtuale. II sistema consente, inoltre, di verificare la qualità dei ritmi di composizione architettonica estratti/astratti, nonché di modificare induttivamente i rapporti e le proporzioni degli elementi abbozzati. Tra gli obiettivi raggiunti, un significativo passo in avanti nell'utilizzo integrato dei metodi analogici/digitali ai fini conoscitivi e dunque, conformativi e comunicativi. Tra gli obiettivi prefigurati, la promozione di nuovi metodi e categorie per esplorare in modo concreto le potenzialità future della rappresentazione architettonica.

\section{Parole chiave}

strategie di rappresentazione numeriche/analogiche, studio e divulgazione digitale, prospettiva cubica, immersione, modelli interattivi.

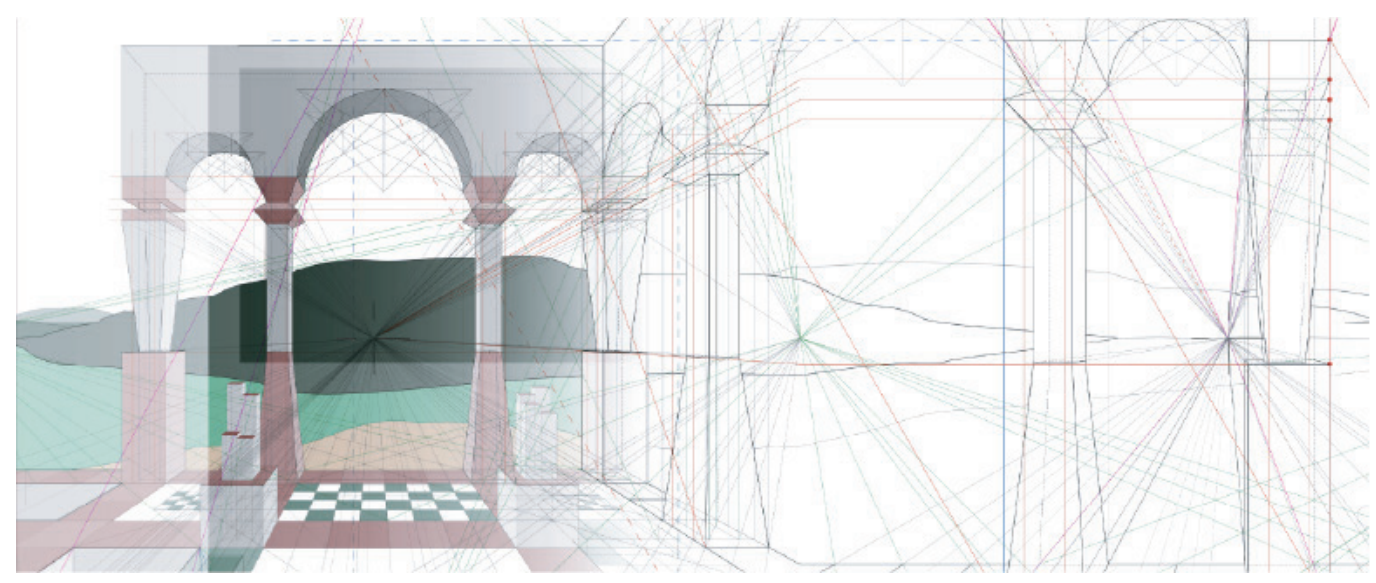




\section{Introduzione}

Le procedure entro le quali il pensiero si formalizza non sono prive di impatto sui risultati finali. Lo ricordava Plinio il Vecchio nel lontano I secolo d.C. [Gaio Plinio Secondo 77-78, p. $15 \mathrm{I}$, lo confermano oggi le applicazioni informatiche in grado di integrare funzioni di calcolo e archiviazione. Le tecnologie digitali interpongono, tra mano e mente, una procedura automatizzata che, se da un lato limita la libertà del disegnatore, dall'altro guida le analisi orientando le scelte [Rossi 20I4]. La pianificazione delle fasi pone dei limiti alle capacità sensoriali/ cognitive dell'operatore ma, allo stesso tempo, genera un nuovo modello operativo che indirizza a risultati innovativi [Rossi 20 I5]. Ciò è confermato anche dalle classi di categorie di possibilità utilizzate per tradurre i codici grafici in codici digitali. La maggiore astrazione consente di rimuovere vincoli, raggruppare attività e isolare insiemi di classificazioni. Queste operazioni potrebbero portare a un nuovo apprezzamento del valore della rappresentazione manuale. II presente lavoro vuole essere un passo in quella direzione che difende un originale approccio di interesse alla ricerca nel settore scientifico e culturale della disciplina.

\section{Lo stato dell'arte}

Tra le prospettive immersive scegliamo la cubica per i suoi vantaggi grafici. Lo sviluppo piano consente l'utilizzo di strumenti e metodi familiari al lavoro dell'architetto, giacché, la deformazione prospettica in ogni faccia implica una distorsione lineare, diversamente da quanto accade nelle prospettive sferiche curvilinee come dimostrano le immagini equirettangolari o le azimutali equidistanti [Araújo et al. 2020; 2019]. Alla data, le prospettive cubiche trovano largo impiego nella computer grafica. Non mancano applicazioni artistiche e solo raramente sono utilizzate nell'architettura [Olivero et al. 2019; Olivero, Sucurado 2019].

La tecnica CGI (da Computer Generated Imagery, meglio nota come 'mappatura cubica' è utilizzata per la creazione degli scenari impiegati nei videogiochi [Donnelly 2007]. Traendo origine dalla mappatura di ambienti effettuata da Ned Greene nel 1986, le scene (meglio conosciute come 'mondi') hanno rivoluzionato il settore, aumentando le prestazioni di rendering grazie alle caratteristiche geometriche del cubo. Da allora, sono stati proposti numerosi miglioramenti e variazioni di illuminazione come, ad esempio, QSC (Quadrilateralized Spherical Cube), regolazione continua e tangente, UniCube e altri [Dimitrijević et al. 20I6]. Ai fini artistici illustrativi sono impiegati effetti web e soluzioni semiautomatiche [cfr. Oniride 360 Art Plugin]. In architettura, invece, le applicazioni di mappatura cubica sono limitate a piccoli interventi estetici in post-produzione, come ad esempio l'oscuramento nelle immagini del treppiede che sostiene la testa ruotante per ritrarre i panorami sferici o, in alternativa, per la colorazione della nuvola di punti [Rossi 2017].

Appare a tal punto evidente come le applicazioni correnti mostrino di sottovalutare le potenzialità del metodo che ci proponiamo di mostrare come sistema adatto all'analisi del già fatto (il costruito) oppure alla verifica del da farsi (progettato). A tal fine occorre innanzitutto padroneggiare i fondamenti matematici del modello cubico per oltrepassare l'incertezza dell'approccio 'how-to veloce e amichevole'.

II principale problema da risolvere in quest'ottica è la rappresentazione di una linea che sviluppata sull'atlante cubico risulta spezzata [Araújo 2020, p. 36;2019, pp. 33, 34].A tal fine, gli autori hanno sviluppato due metodi. Nel primo metodo, si è affrontato il problema della frammentazione considerando l'unione disgiunta di sei prospettive lineari [Olivero 20 I9]. Nel secondo, si tratta la prospettiva cubica come un caso particolare di prospettiva sferica [Araújo 2020]. Per le applicazioni presentate nel documento si è scelto di seguire il secondo metodo, poiché:

- risolve tutte le possibilità di rappresentazione (non solo su linee parallele alle facce del cubo);

- propone una soluzione compatta, che implica avere tutti i punti di fuga e le loro costruzioni ausiliarie entro i confini del foglio;

- integra il nostro lavoro all'interno della teoria generale sviluppata per altre prospettive sferiche, sia fisheye [Araújo, 20।8a] che 'equirettangolare' [Araújo 20 I 8b]. 


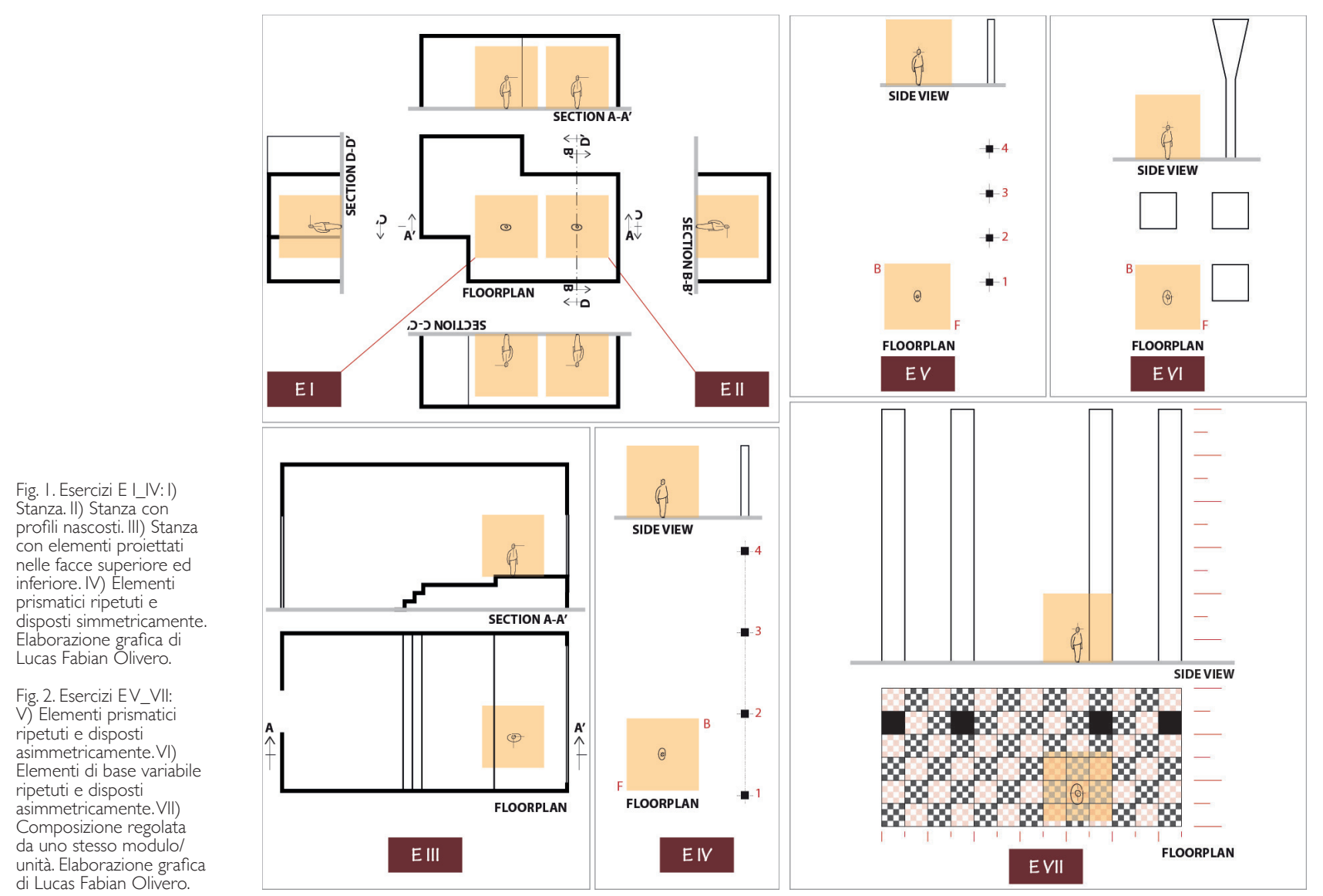

\section{Metodo}

Si introduce la teoria della prospettiva cubica presentando applicazioni di crescente difficoltà. I primi sette esercizi (El - E VII) portano a risolvere problemi di base applicati ad elementari spazi di architettura (figg. I, 2). Le procedure sono state testate anche sul piano didattico (corso di Tecniche Avanzate della Rappresentazione a.a. 20 I9-2020 A. Rossi Unicampania). I disegnatori, nel nostro caso gli studenti, visualizzano l'anamorfosi costruita nello sviluppo della prospettiva cubica (figg. 3-7) ricorrendo ad una soluzione semiautomatizzata (Plugin 360 Art per Photoshop 20 15.5), scegliendo di seguire un work flow con un software free source (e.g. Hugin) oppure in alternativa ricorrendo a soluzioni online (e.g. 360Toolkit) [Olivero 2020; Rossi 2020].

I successivi esercizi di sintesi soffermano l'attenzione sul disegno di uno spazio ideale o sull'analisi di uno spazio esistente, per convergere (partendo da due poli opposti) sul medesimo obiettivo conoscitivo-conformativo.

La prima applicazione di sintesi (EVIII) prende dunque le mosse da una struttura geometrica ipotizzata in pianta e in alzato (cultura del progetto): l'operatore applica la casistica acquisita con lo sviluppo degli esercizi (E I-VII) per ricercare poi nell'impalcatura geometrica (ovvero nella struttura della prospettiva cubica) le ragioni dei rapporti e delle proporzioni che definiscono forme architettoniche e, viceversa, controllare le relazioni tra gli elementi ipotizzati e rappresentati (fig. 8).

In ogni momento, l'anamorfosi cubica può essere verificata digitalmente nella forma 3D offrendo la possibilità di una visione vincolata che rende lo spazio virtuale chiaramente identificabile. In questo modo, l'utente osserva a tutto campo il proprio prodotto dall'interno dello spazio. Dall'alternanza dei punti di vista (interno/esterno), lo studioso può visualizzare gli aspetti essenziali delle sue analisi/ipotesi prima di ricorrere alla una dettagliata modellazione 3D. 
Fig. 3. Interpretazione spaziale degli esercizi I e II (sopra). Sviluppo del cubo (sotto).

Elaborazione grafica di Teresa di Palma.TAR a.a. 2019/20. Dipartimento Ingegneria Unicampania (prof. A. Rossi).

Fig. 4. Composizione libera in base alla

stanza dell esercizio II.

Visualizzazione immersiva

struttura geometrica/

render (sopra)

Composizione cubica

(sotto). Elaborazione

grafica di Teresa di Palma

e Assia d'Alesio. TAR a.a.

2019/20. Dipartimento di

Ingegneria Unicampania

(prof. A. Rossi).

Fig. 5. Interpretazione spaziale dell'esercizio IV (sopra). Abbozzo cubico realizzato con mezzi tradizionali mezzi tradizionali
(sotto). Elaborazione (sotto). Elaborazion
grafica di Teresa di grafica di Teresa di
Palma.TAR a.a.20 19/20. Palma.TAR a.a.20

Ingegneria Unicampania (prof. A. Rossi).

Fig. 6. Interpretazione spaziale (sopra) e (sotto) dell'esercizio VIl. Elaborazione grafica diTeresa di Palma e Mariateresa Petrosino.

TAR a.a. 2019/20.

Dipartimento di

Ingegneria Unicampania Ingegneria Unicamp
(prof. A. Rossi).
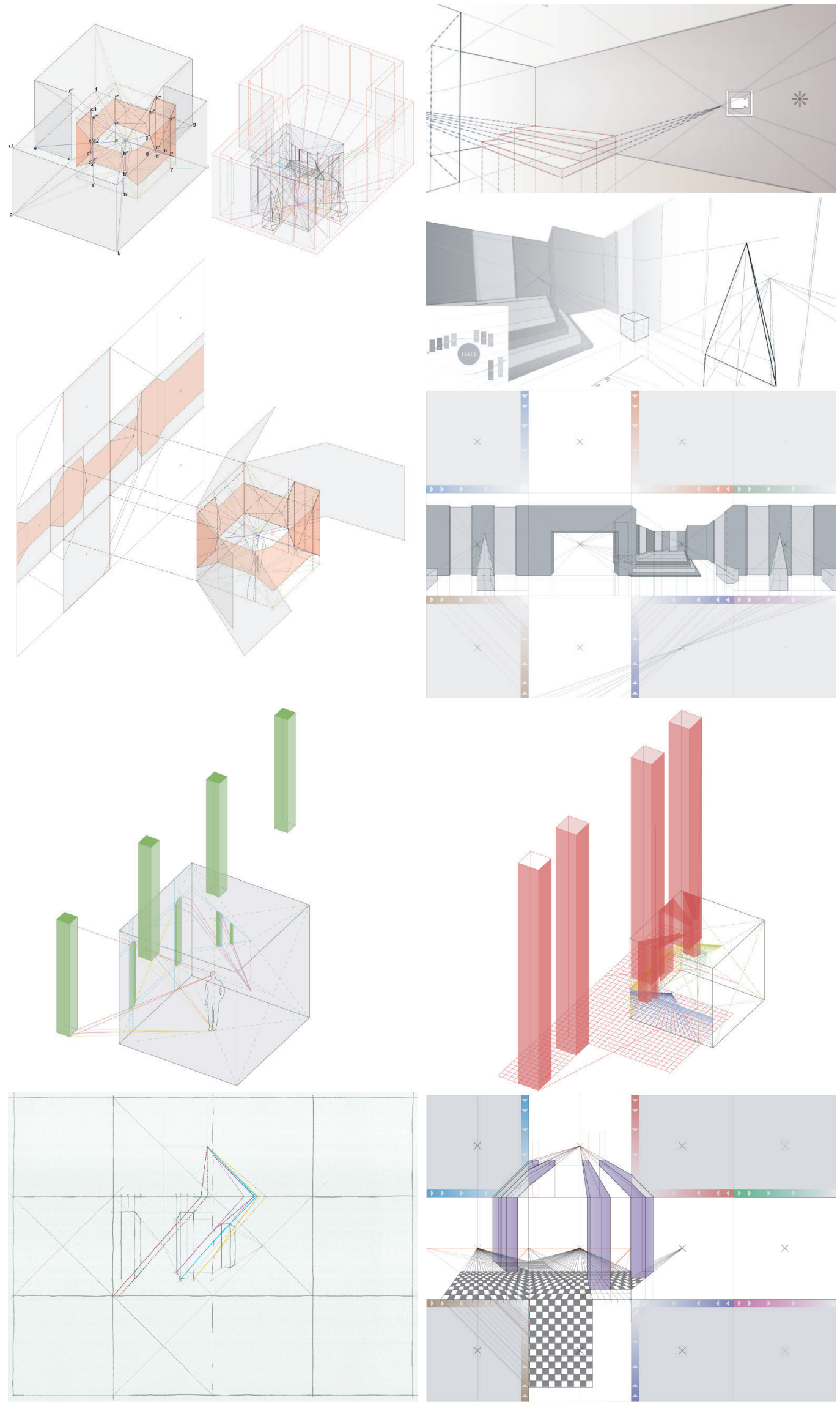
Fig. 7.Visualizzazione immersiva struttura geometrica/render degli esercizi $V$ (sopra) e VII (sotto). Elaborazione grafica di Assia d'Alesio. TAR a.a. 2019/20.

Dipartimento di

Ingegneria Unicampania (prof. A. Rossi).

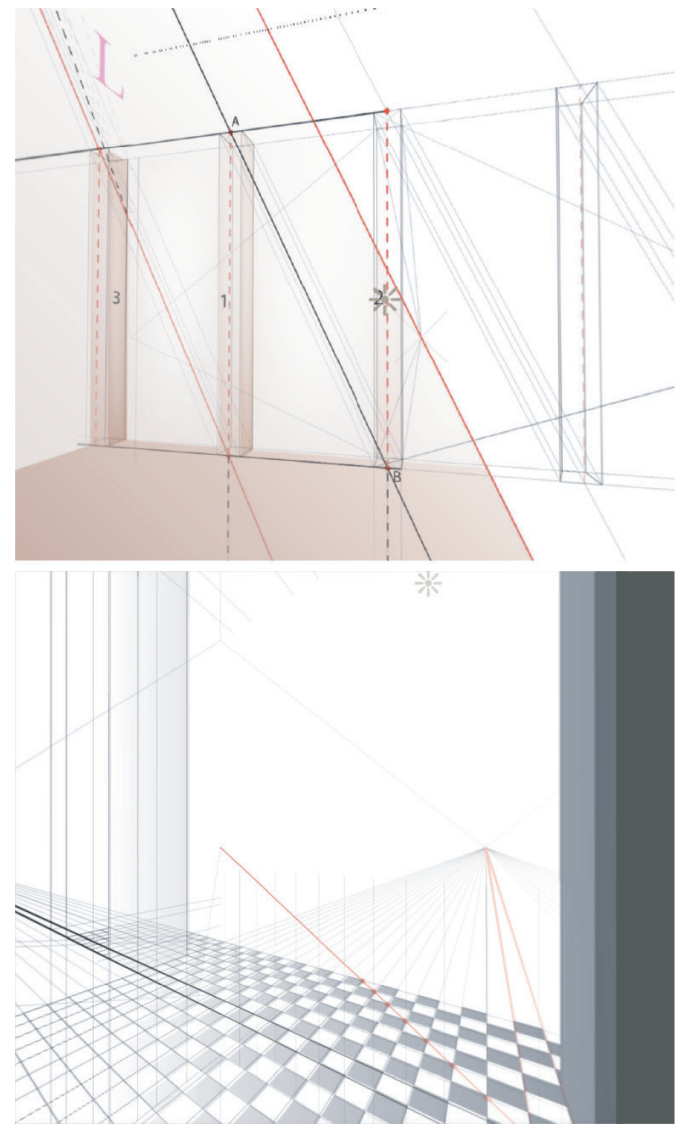

La seconda applicazione di sintesi (E IX) prende l'avvio dallo stato di fatto (cultura del rilievo). Emblematico per il tipo di analisi l'interno della fabbrica Solimene (Vietri sul Mare, 1950-1955), un edificio scelto a campione sia per la suggestiva articolazione dello spazio interno, sia perché rilevato dagli autori con ogni sorta di strumento e dunque ricostruito in digitale con tecniche di modellazione informativa [Rossi 20।7; 20। 8; 2019;2020). L'analisi effettuata sui panorami consente verifiche scientifiche e culturali sul metodo adottato originale e innovativo per la sua fondatezza matematica.

Ipotesi di lavoro due giga-panorami fotografici (uno esterno e uno interno) acquisiti coprendo ognuno un campo visivo di $360^{\circ}$ sull'asse verticale e di $180^{\circ}$ sull'orizzontale. I molteplici scatti fotografici catturati con l'ausilio di una testa panoramica motorizzata (Gigapan Epic Pro) sono stati sovrapposti e ricuciti digitalmente utilizzando un software dedicato (Color Autopano Giga), per generare in uscita il panorama in proiezione 'equirettangolare' (fig. 9).

Come è noto, è possibile proiettare l'occhio dell'osservatore nel primo centro nodale della fotocamera, così da consentirgli di ispezionare in modo immersivo l'interno di una sfera ideale il cui raggio misura la distanza tra il centro nodale e la superficie spalmata del mosaico fotografico.

Un'analoga esperienza può farsi sostituendo la superficie sferica con una superficie cubica (fig. 9) per condividere lo stesso panorama e quindi le informazioni grafiche (matematicamente, un omeomorfismo). II rapporto cubo/sfera, ormai sviluppato a livello informatico grazie all'Environmental Mapping, il panorama fotografico è stato convertito in proiezione cubica e quindi trascritto in vettoriale.

Nel leggere le relazioni fra elementi architettonici, l'operatore verifica ipotesi interpretative (fig. I0) ma anche la correttezza matematica delle interpretazioni (fig. I I) come, ad esempio, la costruzione più complessa inerente alle geodetiche [Araújo 2020, pp. 39-42].

Entrambi gli esercizi di sintesi focalizzano l'attenzione sulla possibilità di recuperare la continuità virtuale dello spazio-tempo, per esperire fisicamente quanto rappresentato. Dalla 
Fig. 8. Composizione finale cubica dell'esercizio VIII (sotto) e visualizzazione Elaborazione grafica di Assia d'Alesio.TAR 2019/20. Dipartimento Ingegneria Unicampania (prof. A. Rossi).

Fig. 9. Acquisizione panoramica a tutto campo della fabbrica di ceramiche Solimene. Formato equirettangolare (sopra) cubico (sotto) e visualizzazione immersiva (centro). Elaborazione grafica di Lucas Fabian Olivero.
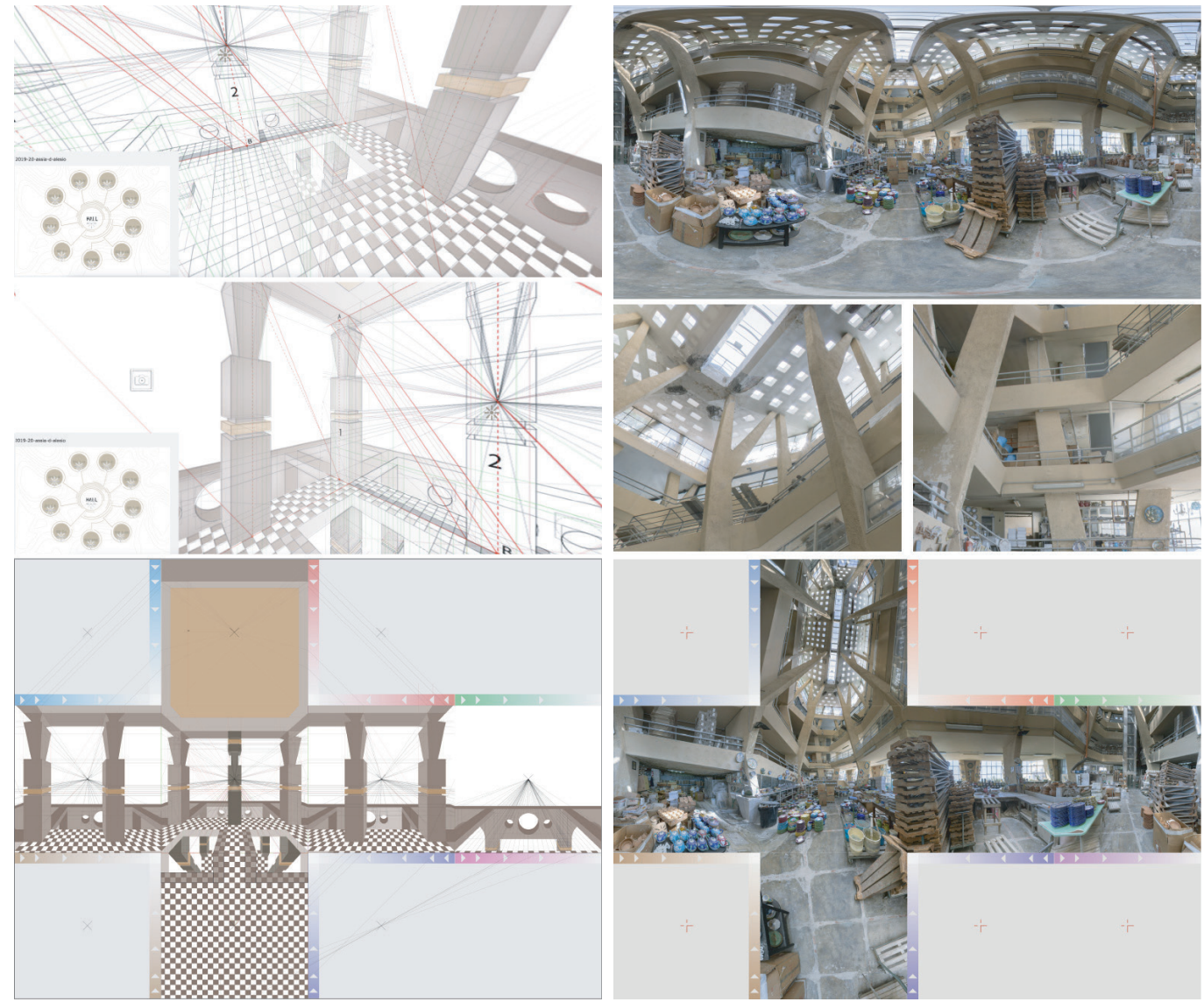

conoscenza acquisita mediante il contatto diretto con un determinato aspetto della realtà, deriva un processo di ridefinizione delle conoscenze e dei concetti. I modelli ibridi offrono pertanto un'opportunità alternativa all'analisi dell'esistente o viceversa alla verifica del progetto. La modalità immersiva offre l'opportunità di toccare il limite tra ciò che esiste o potrebbe esistere, tra ciò che "si può e non si può fare" [Purini 1996, p. 15].

\section{Deduzioni}

Le applicazioni discusse nell'articolo ci hanno dato la possibilità di verificare a livello di critica operativa le basi teoriche della prospettiva cubica. I casi di studio analizzati hanno permesso di introdurre uno degli aspetti più interessanti della nostra attuale ricerca nel campo della rappresentazione architettonica. La fruizione immersiva di ambienti costruiti in prospettiva cubica o di ambienti resi attraverso le sue regole, sono stati utilizzati come sistema per esplorare, verificare e comunicare esercizi indirizzati a condurre un'analisi conoscitiva nel secondo caso e un'esplorazione ideativa nel primo.

Al passo con i nostri tempi e in linea con gli strumenti e le modalità disciplinari abbiamo analizzato le potenzialità innovative del modello ibrido che coniuga l'originalità degli schemi compositivi con la loro navigazione digitale. La procedura confrontabile e verificabile, in virtù della sua natura scientifica, traccia un ulteriore passo avanti nell'integrazione di metodi e linguaggi di comunicazione visiva e multimediale. Gli siti mostrano allo studioso una duplice opportunità: da un lato la possibilità di sfruttare la rapidità e l'immediatezza del pensiero cognitivo intuitivo reso oggettivo dai segni grafici, e, dall'altro, la possibilità di cogliere vantaggio, dal punto di vista speculativo, dell'efficacia di fruizione di tecniche immersive che consentono all'operatore di vivere scenari digitali. 


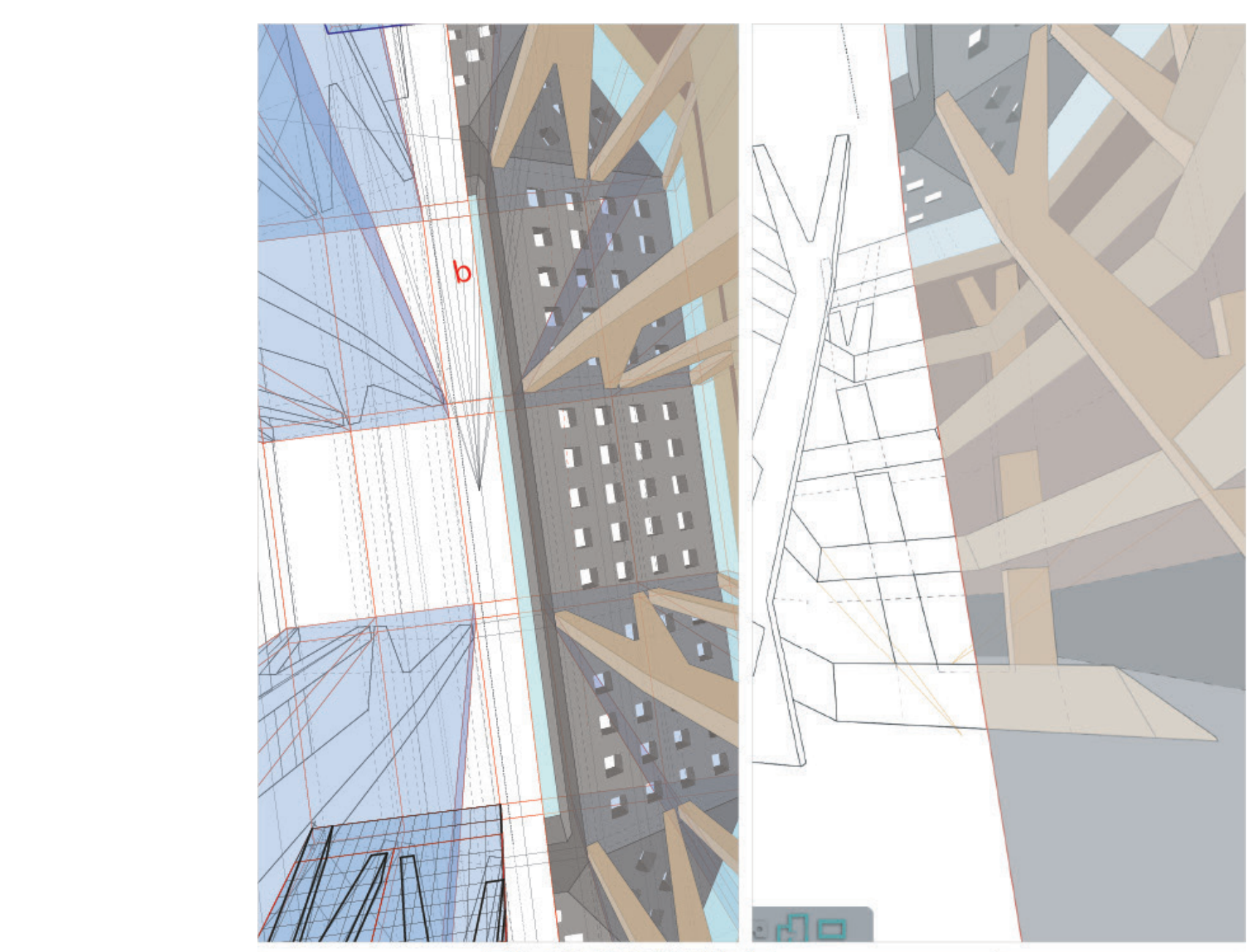

Fig. 10. Esercizio di sintesi E IX (cultura del rilievo). Analisi degli elementi compositivi, punti di fuga e linee geodetiche utilizzate (sotto).

Visualizzazione immersiva (sopra). Elaborazione grafica di Assia D'Alessio, Teresa Di Palma,

Caterina Crispino, Marta Campanile, Maria Petrillo e Lorenzo Villani.

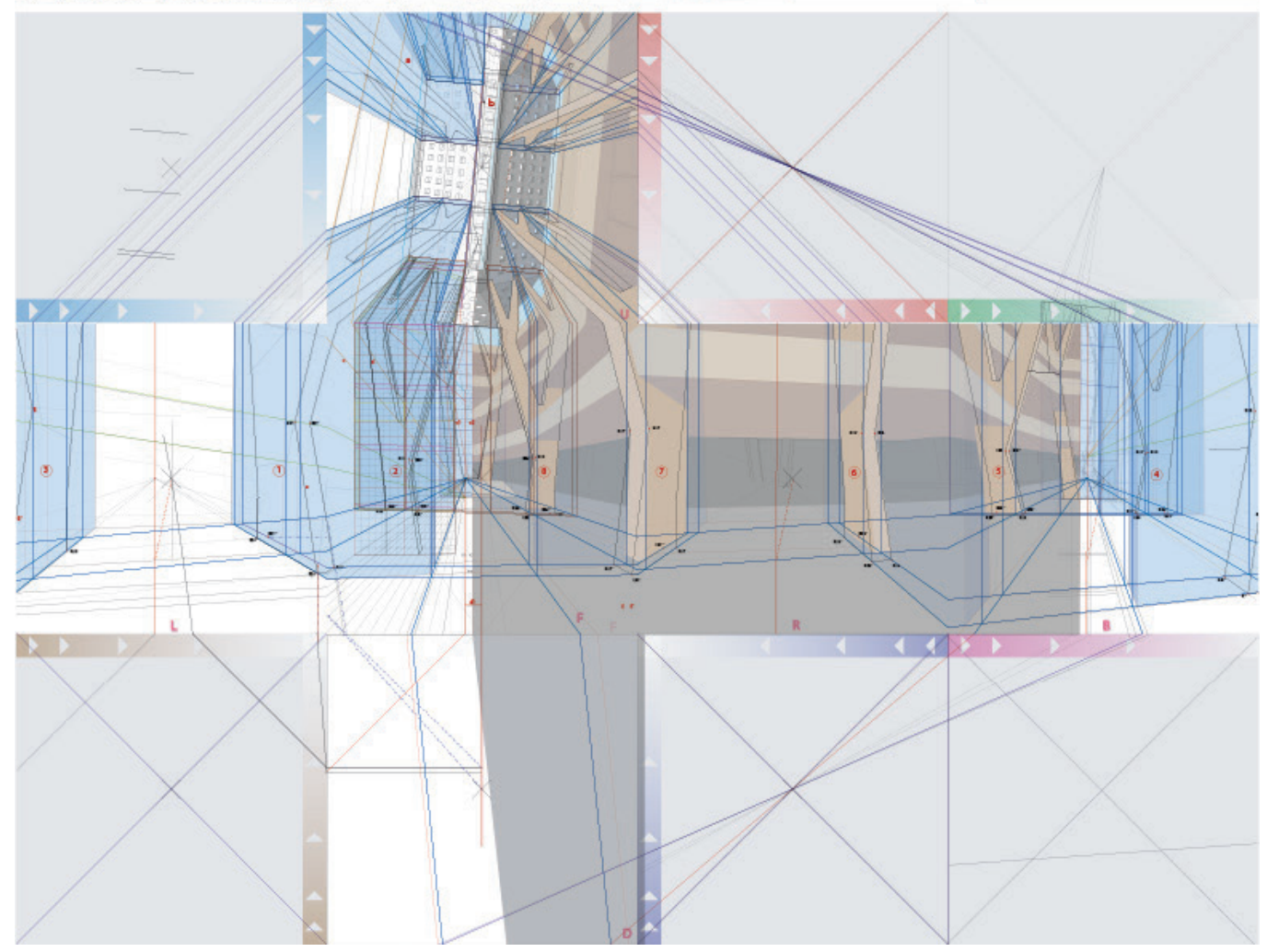





Fig. I I. Esercizio di sintesi Composizione cubica con delle linee geodetiche

a partire dei valori

medi (sopra). Dettaglio

dei criteri matematici

adottati. Elaborazione

grafica di Lucas Fabian 


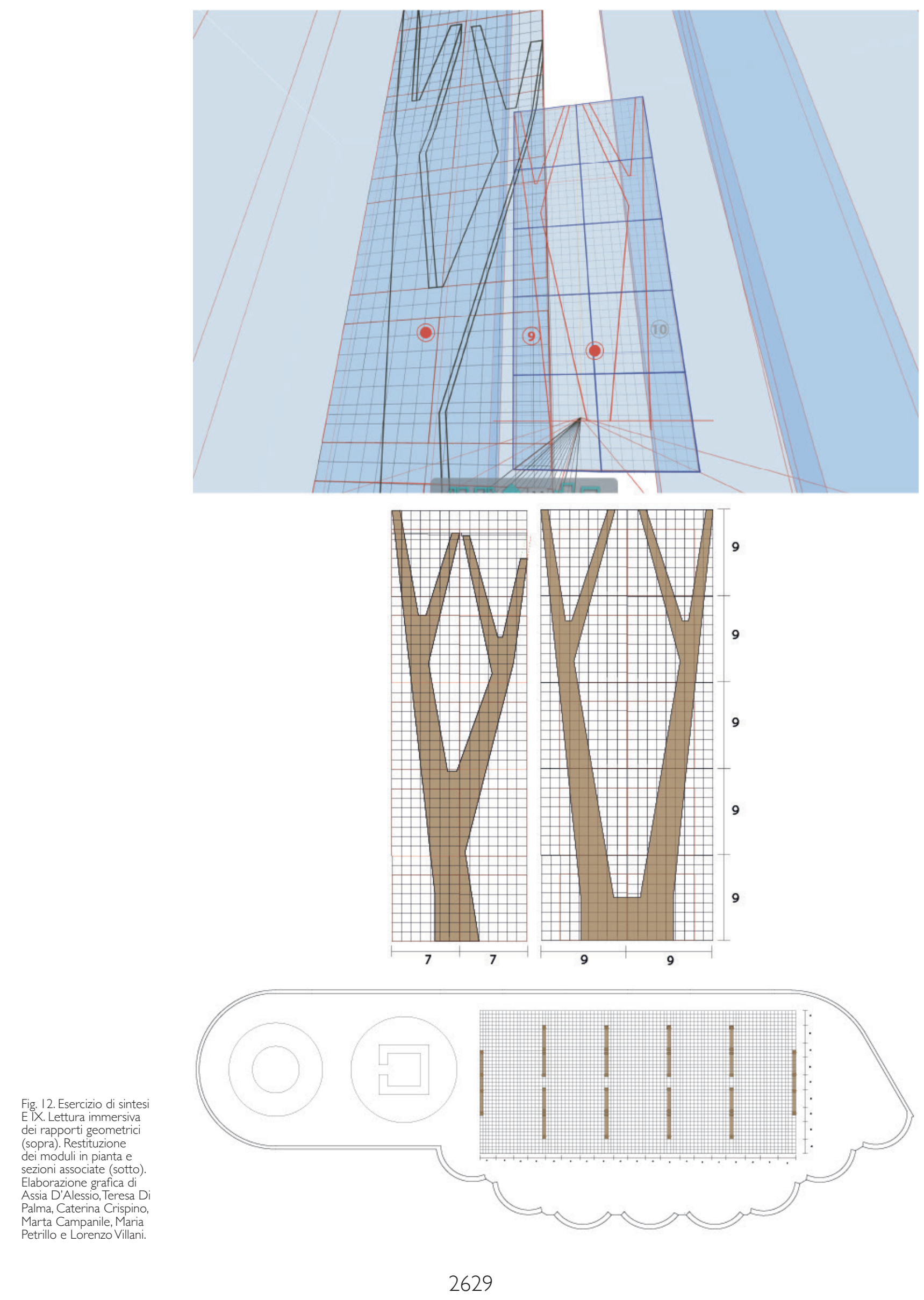




\section{Risultati raggiunti e attesi}

I lavoro presentato in questo contributo sollecita un processo rappresentativo prima che illustrativo. Focalizzandosi sulla capacità squisitamente umana di estrarre/astrarre elementi architettonici dalla complessità del contesto foto-realistico distingue gli elementi portati dai portanti. II dato permette di manipolare, con maggiore consapevolezza, le interpretazioni (cultura del rilievo) o, inversamente, verificare la qualità di ritmi composizioni (cultura del progetto). La procedura, basandosi sul dominio dei fondamenti scientifici della geometria descrittiva, integra l'intuizione dello schizzo con la virtualità digitale. Lo spazio di collaborazione (AR-VR), inizialmente ricavato adattando, con l'ausilio di applicazioni informatiche, composizioni di prospettive piane [Rossi, Olivero 20 I8], si articola, attualmente, sul dominio di una serie di soluzioni scientifiche, talvolta abbreviate, utili a dominare matematicamente il potenziale dei segni grafici per governarne il passaggio dall'interpretazione al controllo progettuale.

Per i cultori del disegno di architettura, infatti, la principale questione aperta e dibattuta attiene l'uso delle tecniche e la loro potenzialità di diventare 'leve intellettive' nel processo di studio e conformazione dello spazio progettuale. Le modalità esecutive proposte a questo fine sono vantaggiose giacché il modello è sviluppabile nel piano e gli strumenti sono quelli tradizionali: con righe e compassi s'interpolano i punti necessari a costruire l'ossatura portante dello schema navigabile digitalmente. L'esito offre una cornice di riferimento entro la quale l'osservatore, divenuto fruitore, è guidato, secondo precisi criteri, a ripercorre le relazioni stabilite [Rossi et al. 2020]. Mutando il tipo di vista, muta il tipo di percezione. Allinterno del template concettuale e applicativo, il sistema orienta verso la formazione di quelle che Martin Heidegger (il tedesco, considerato il maggior esponente dell'esistenzialismo ontologico) ha chiamato "nuove immagini del mondo" [Heidegger 1954]. Passeggiare in uno spazio ripresentato, quando non si esaurisce tautologicamente in un'autistica virtualità, rende l'esperienza fluida e immediata, aiuta a familiarizzare con il problema da analizzare e risolvere, modifica in tempo reale il rapporto tra osservatore e oggetto. Nei modelli navigabili la sensazione visiva si correla alla percezione visiva così che il connubio avvia un processo intellettivo che partecipa attivamente alla razionalizzazione del pensiero e quindi alla sua rifondazione. Va da sé che quanto più il sistema è adattabile alla navigazione immersiva, tanto più i contenuti si plasmano in funzione della cultura dell'utente, dei suoi desideri e aspettative, registrabili con estrema precisione e rapidità con i sistemi tecnologici posti a disposizione.

Nonostante la posizione fissa assunta dal fruitore di fatto inchiodato nel centro dello spazio cubico, lo sguardo è libero di spaziare a tutto campo per validare fattori che possono contribuire a definire la qualità di quanto appreso e classificato. Questa è la procedura che, affiancando le precedenti impiegate per lo studio della fabbrica Solimene, ci permette di approfondire aspetti interessanti della nostra attuale ricerca nel campo della rappresentazione architettonica. Tra i vantaggi resi confrontabili si riscontra la possibilità di: "rimediare" il valore degli schizzi a mano; razionalizzare le configurazioni degli elementi architettonici; sviluppare in automatico con i medesimi dati 2D (poche primitive visuali o grafiche) uno spazio 3D semplificato rispetto alla consueta modellazione di volumi assai più elaborata poiché indirizzata ad altri scopi; validare i work-flow richiesti dalle procedure automatizzate dedicate al montaggio di panorami e, non da ultimo, incentivare l'indagine olistica sullo spazio configurato.

\section{Crediti}

L.F. Olivero è neo-Dottore di Ricerca in Ambiente, Design e Innovazione, è stato finanziato dall'Università della Campania "Luigi Vanvitelli", Italia. Titolo della tesi: Hybrid Immersive Models from cubical perspective drawings (Modelli Ibridi Immersivi da disegni in prospettiva cubica). II tutor della tesi è stata PhD A. Rossi, professore ordinario presso il Dipartimento di Ingegneria dell'Università della Campania, Italia. II tutor internazionale è stato PhD A.B. Araújo, professore assistente presso l'Universidade Aberta, Portogallo. Da marzo 202 I, L.F. Olivero è alla data finanziato dalla FCT (Portogallo) per il conseguimento di un secondo dottorato di ricerca in Media e Arte Digitale, presso I'Universidade Aberta e Universidade do Algarve, Portogallo. 


\section{Riferimenti bibliografici}

Araújo A.B. (2018a). Ruler, compass, and nail: Constructing a total spherical perspective. In Journal of Mathematics and the Arts, n. 12 (2-3), pp. $144-169$.

Araújo A.B. (20।8b). Drawing Equirectangular VR Panoramas with Ruler, Compass, and Protractor. In Journal of Science and Technology of the Arts, n. 10 (I), pp. I 5-27.

Araúijo A.B., Olivero L.F., Rossi A. (2019). Boxing the Visual Sphere:Towards a systematic solution of the cubical perspective. In Belardi P. (a cura di). REFLECTIONS the Art of Drawing | the Drawing of Art, pp. 33-40.

Araújo A.B., Olivero L.F., Rossi A. (2020). A Descriptive Geometry Construction of VR panoramas in Cubical Spherical Perspective. In Diségno, n. 6, pp. 35-46.

Carbone E. (2017). An ancient space-time revisited. Computer models for documentation and optimization of the Environmental Heritage. In Rossi A. (a cura di). Immersive high resoluttion photographs for cultural heritage. Drawing/Disegno. vol. 2, pp. |03- | | 5. Padova: libreriauniversitaria edizioni.it.

Dimitrijević A.M., Lambers M., Rančić D. (2016). Comparison of shperical cube map projections used in planet-sized terrain rendering. In Facta Universitatis, Series: Mathematics and Informatics, n. 3 I (2), pp. 259-297.

Donnelly P. (2007). Video game play using panoramically-composited depth-mapped cube mapping (United States Patent No. US7256779B2)

Gaio Plinio Secondo (77-78). Storia naturale, V. Mineralogia e storia dell'arte. Libri 33-37. Tr. it. Corso A., Mugellesi R., Rosati G. Torino: Einaudi 1988.

Heidegger M. (1954). Che cosa significa pensare? Milano: SugarCo Edizioni 1996

Olivero L.F., Araújo A.B., Rossi A. (2020). Applications of Cubical Perspective in Architecture, Engineering and Product Design. In Fátima Silva M. et al. (a cura di), 4. ${ }^{\circ}$ Seminário Internacional de Arquitectura e Matemática, Universidade Lusíada, vol. I, pp. 6386. Lusíada: Universidade Lusíada.

Olivero L.F., Rossi A., Barba S. (2019). A codification of cubical projection for the generation of immersive models. In Diségno, n. 4, pp. 53-63.

Olivero L.F., Sucurado B. (2019). Analogical immersion: Discovering spherical sketches between subjectivity and objectivity. In ESTOA. Revista de la Facultad de Arquitectura y Urbanismo de la Universidad de Cuenca, n. 8( I 6), pp. 47-59.

Purini F. (1996). Una lezione sul disegno (First Edition edition). Roma: Gangemi.

Rossi A. (2014). Introduzione al disegno informatico per l'architettura e l'ingegneria edile. Torre del Greco (NA): Edizioni Scientifiche e Artistiche.

Rossi A. (20I5). II Vero si prolunga nel Verosimile. In Bartoli M.T., Lusoli M. (a cura di). Le teorie, le tecniche, i repertori figurativi nella prospettiva d'architettura tra il '400 e il '700: Dall'acquisizione alla lettura del dato. Firenze: University Press, pp. $335-346$.

Rossi A. (2017). The Façade of Paolo Soleri's Solimene Factory. In Nexus Network Journal, n. 19(2), pp. 503-520.

Rossi A. (20 18). El analisis de la forma en el diseno arquitectonico: Desde el projecto a la ejecucion/The analysis of the form in the architectural design: from the project to the execution Between survey and design: the work in progress variations. In EGA. Revista de expresión gráfica arquitectónica, n. 22(32).

Rossi A. (2019). BIM - OGGI - ITALIA. Drawing/Disegno. vol. 3. Padova: libreriauniversitaria edizioni.it.

Rossi A., Olivero L.F. (20I8). Immersive models from analogical sketches applied to Solimene's Factory. In EGRAFIA. Argentina: UniRío Editora.

Rossi A., Olivero L.F., Araújo A.B. (2020). For Representation, a New Reality: Hybrid Immersive Models. In Magnaghi-Delfino P. (a cura di). Faces of Geometry 2020. Cham: Springer International Publishing.

Rossi A., Palmieri U. (2020). Modelling Based on a Certified Level of Accuracy: The Case of the Solimene Façade. In Nexus Network Journal, n. 22(3), pp. 615-630.

Autori

Adriana Rossi, Università degli studi della Campania “Luigi Vanvitelli”, adriana.rossi@unicampania.it Lucas Fabian Olivero, Università degli studi della Campania “Luigi Vanvitelli”, lucasfabian.olivero@unicampania.it António Bandeira Araújo, Universidade Aberta, antonio.araujo@uab.pt

Per citare questo capitolo: Rossi Adriana, Olivero Lucas Fabian, Bandeira Araújo António (2021). Spazi digitali e modelli immersivi: applicazioni di prospettiva cubica/Digital Environments and Immersive Models: Applications of Cubical Perspective. In Arena A., Arena M., Mediati D., Raffa P (a cura di) Connettere Un diseono per annodare e tessere Linguagoi Distanze Tecnologie. Atti del $42^{\circ}$ Convegno Internazionale dei Docenti delle Discipline della RappresentazionelConn Conference of Representation Disciplines Teachers. Milano: FrancoAngeli, pp. 2621-2642. 


\title{
Digital Environments and Immersive Models: Applications of Cubical Perspective
}

\author{
Adriana Rossi \\ Lucas Fabian Olivero \\ António Bandeira Araújo
}

Abstract

Composition exercises of increasing difficulty are aimed at assessing the acquisition of the rules of cubical perspectives previously elaborated. The built environments were made immersive thanks to dedicated software. The operator is thus virtually projected into the centre of the cubical space and is, therefore, free to visualize the entire space to analyse each aspect considered. The experience allows to self-correct the discontinuity errors made in the execution of cubical perspectives which become evident in the virtual space. It also enables to verify the quality of the extracted/abstracted composition rhythms, as well as inductively adjust the ratios and proportions of the sketched elements.

Amongst the achieved objectives, the main result is a significant step forward in the use of analogue/ digital methods for an architectural drawing for cognitive, conformative and communicative purposes.

Keywords

numerical/analogical representation strategies, digital study and dissemination, cubical perspective, immersion, interactive models.

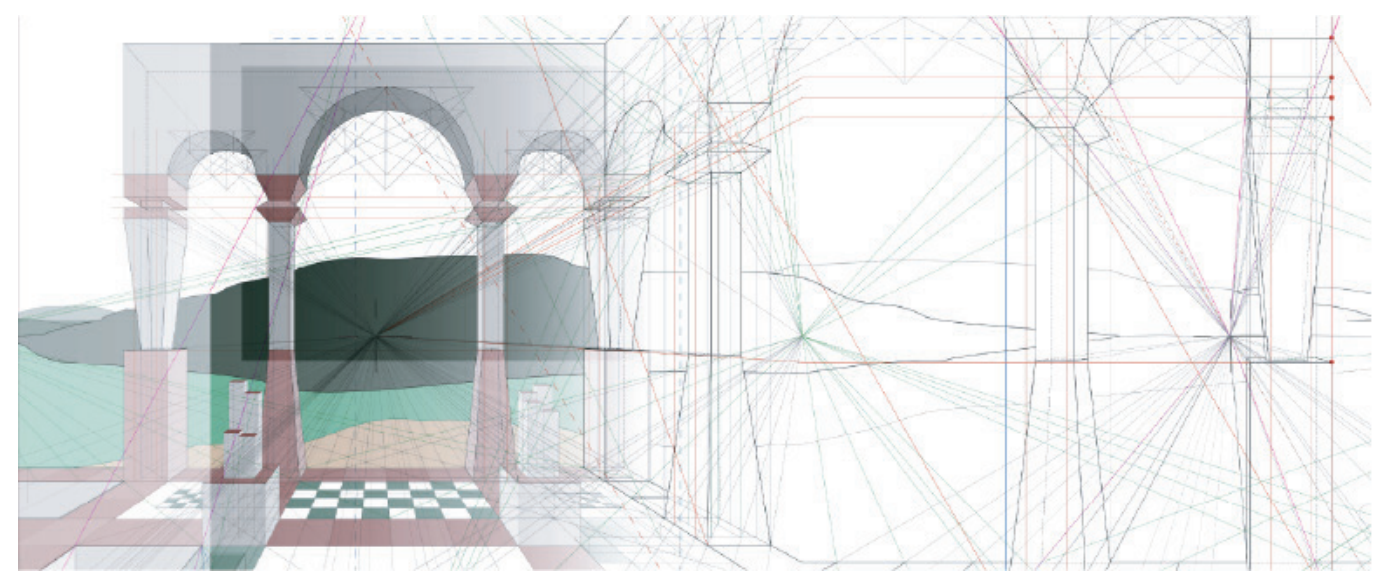




\section{Introduction}

The procedures through which thought is formalized are not without impact on such formalizations or outcomes. Pliny the Elder had already expressed this view in the Ist century B.C. [Gaio Plinio Secondo 77-78, p. 15I]. Today, this is also confirmed by digital technology applications that can integrate computation and archiving functions. This happens, for example when an automatized procedure, governed by software instructions, is introduced between conception and execution [Rossi 20 I4].The planning of the phases undoubtedly sets limits to the sensory/ cognitive capabilities of the operator but at the same time, it generates a new operational model that very often brings about innovative results [Rossi 20I5]. This is also confirmed by the classes of possibility categories used to translate graphical codes into digital codes. The greater abstraction allows to remove constraints, group tasks and isolate more consistent classification sets. These operations might lead to a novel appreciation of the value of manual representation. The present work is intended as a step in that direction that defends an original approach of interest to the research in the scientific and cultural sector of the discipline.

\section{The state of the art}

Among the various immersive perspectives, we choose the cubical perspective because of its advantages to our purposes. Cubical perspective methods are associate with linear drawings methods, which recalls a familiarity among architects and designers. On the other hand, perspective deformation in every face of the cube is an intuitive, convenient distortion, which does not always apply to the considerably curved warping of other spherical perspectives. For a more in-depth comparison between cubical perspective and other immersive perspectives check [Araújo 2020; 2019]. The current repertoire of cubical applications is mainly filled by technical applications in the CGI (Computer Generated Imagery) field. There are also some intuitive procedures from the artistic field and just a few examples of applications in the architectural field [Olivero 20 I9; Olivero, Sucurado 20 I9].

The first group, better known as 'cubical mapping', uses the geometry of a cube for scenes creation with ludic purposes, e.g. in videogames [Donnelly 2007]. Started with the Environmental Mapping of Ned Greene in 1986, these scenes (better known as 'worlds') revolutionized CGl increasing rendering and lighting performance thanks to the use of the cube. Since then, several improvements and variations were proposed in a large number of methods: standard cube map, QSC (Quadrilateralized Spherical Cube), continuous, tangent adjustment, UniCube and others [Dimitrijević 2016 ]. The second group of artistic applications re-uses cubical mapping for illustration-artistic purposes. Here we can find both several web tutorials and semi-automatic solutions, such as Oniride 360 Art Plugin. In architecture, we find cubical mapping applications for minor editing (e.g., deleting the tripod or for point cloud colouration) of 360-degree photography during architectural surveys [Rossi 20 17]. In this case, a software tool converts and switches back between the equirectangular and the cubical map format. Other cases get a cubical mapping creating first a 3D model and then using an automated plugin. In both cases, the designer depends on software availability and the programmers' decisions about its implementation. As we can see, this peripheral approach is lukewarmly useful. We see that current applications call on cubical mapping just as a secondary resource (e.g., a last aesthetical intervention in post-production) undervaluing its full potential. Therefore, we aim to consider cubical mapping as a complete instrument for both architecture survey and design. Hence, the trial-and-error knowledge of the current panorama does not give more than a 'quick and friendly how-to' without going into the essence of the representation: the study and properties of the projections on the cube's surface, both with existing and non-existing scenes. To get at this essence it is necessary to master the mathematical fundaments of the cubical model. One main problem of cubical perspective is how to efficiently solve the fragmentation of a line representation [Araújo 2020, p. 36; 2019, pp. 33-34]. Going beyond the existing approaches' limitations, the authors developed two methods. In the first method, we face the fragmentation problem considering the disjoint union of six linear perspectives [Olivero et al., 2019]. In the 

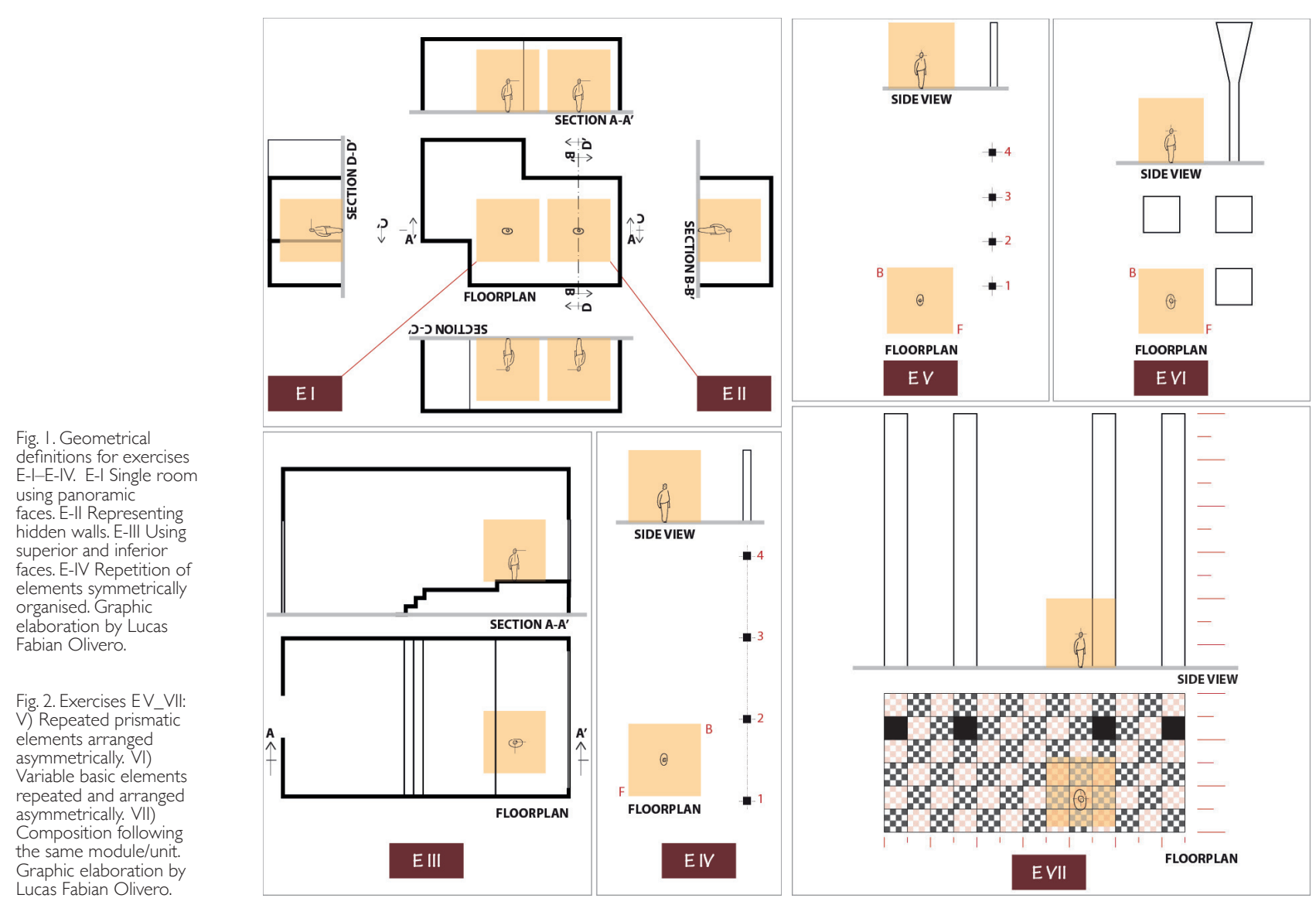

second one, we treat the cubical perspective as a particular case of spherical perspective [Araújo 2020]. For the following applications we have chosen to follow the second method since:

- it solves all the possibilities of representation (the first method solved just lines parallel to the cube's faces);

- it proposes a compact solution, which implies having all the vanishing points and their auxiliary constructions within the confines of the paper;

- it integrates our work within the general theory developed for other spherical perspectives, both fisheye [Araújo 2018a] and 'equirectangular' [Araújo 2018b].

\section{Method}

We introduced the cubical perspective theory through exercises of increasing complexity. The first seven (E-I -E-VII) aim to solve basic problems applied to elementary architectural spaces (figs. I, 2). They were carried out and tested within didactic activities of the curricular course TAR (Advanced Techniques of Representation) a.a. 2019-2020, prof. A. Rossi, Unicampania. The draughtsmen, in our case the students, visualise the anamorphosis constructed in the plane development of the cubical perspective (figs. 3-7) using a semi-automatised solution (Plugin 360 Art for Photoshop 20 I5.5), by following a workflow with a free-source software (e.g., Hugin) or through online solutions (e.g., 360Toolkit) [Olivero 2020; Rossi 2020].

The subsequent exercises of synthesis focus both on the design of ideal space and the analysis of an existing space, to converge (starting from two opposite poles) on the same cognitive-conformative objective.

The first application of synthesis (E VIII) starts from a geometric structure hypothesised in plan and elevation (project culture): the operator applies the knowledge acquired with the previous exercises (E I-VII). Then it searches in the geometric scaffolding (that is, within the cu- 
Fig. 3. Spatial

interpretation of

(above). Development

of the cube (below).

Graphic elaboration by

Teresa di Palma.TAR a.a.

2019/20. Unicampania

Department of

Engineering (prof. A

Rossi).

Fig. 4. Free composition based on the room from exercise II. Immersive geometric structure render visualization (above). Cubic

composition (below). Graphic elaboration by Teresa di Palma and Assia d'Alesio. TAR a.a. 2019/20. Unicampania Department of

Engineering (Prof. A

Rossi)

Fig. 5. Spatial

interpretation of exercise

IV (above). Cubical sketch

realised with traditiona

means (below). Graphic

elaboration by Teresa

di Palma.TAR a.a.

2019/20. Unicampania

epartment of

Engineering (prof. A

Rossi).

Fig. 6. Spatial

interpretation (above)

and cubical composition (below) of exercise VII.

Graphic elaboration

by Teresa di Palma

and Mariateresa

Petrosino.TAR

2019/20. Unicampania

Department of

Engineering (Prof. A

Rossi).
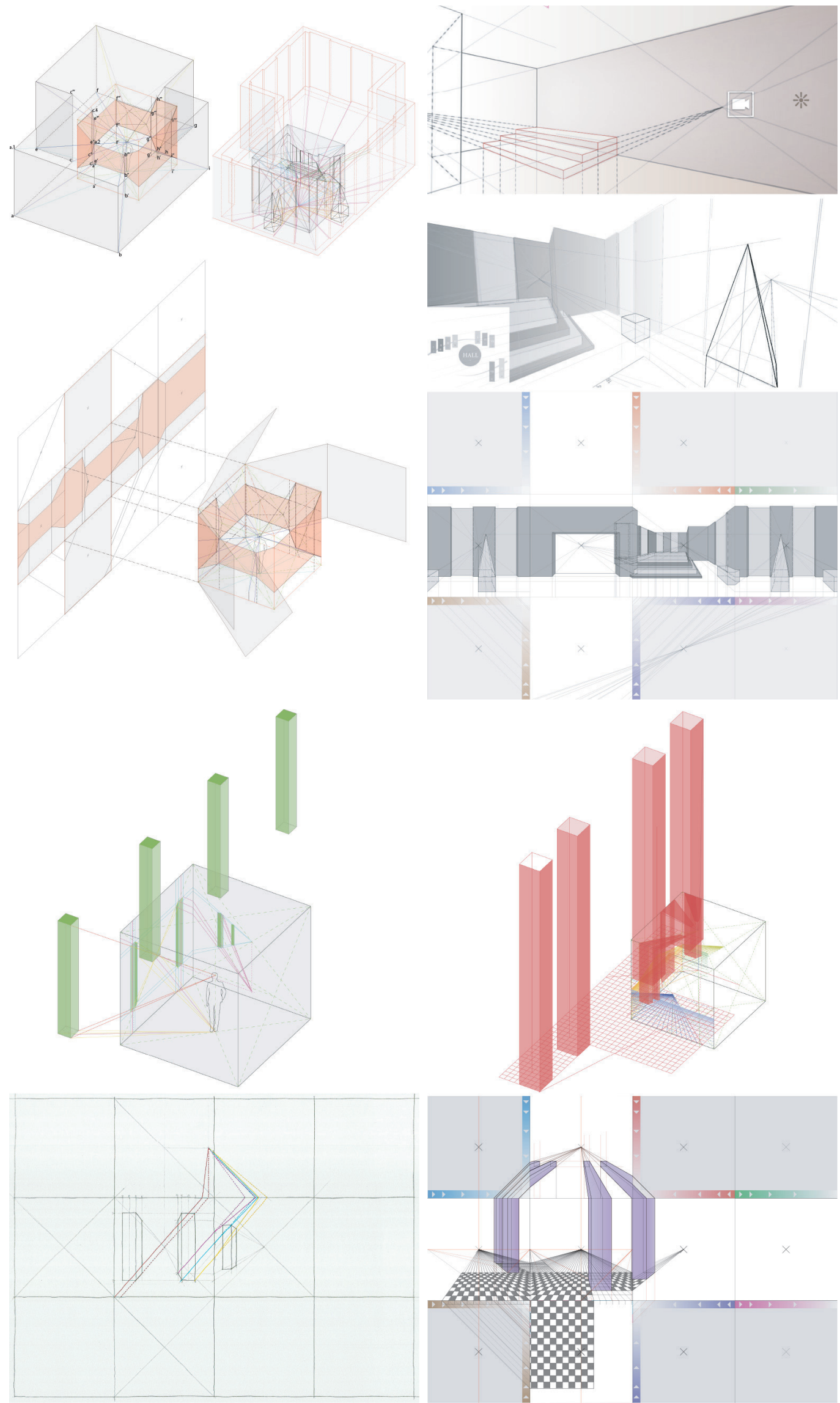
Fig. 7. Immersive visualization: geometric structure/render of exercises $V$ (above) and VII (below). Graphic elaboration by Assia d'Alesio.TAR a.a. 2019/20. Unicampania Department of Engineering (prof. A Rossi).

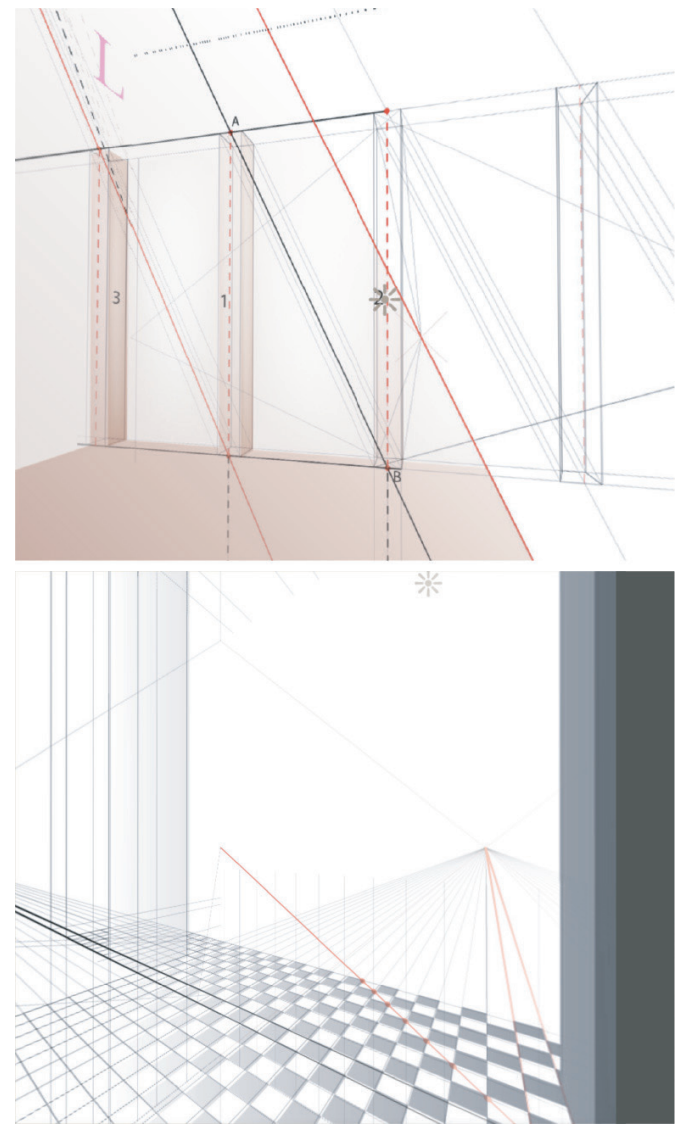

bical perspective) reasons, relationships and proportions that define the architectural shapes and, vice versa, the relationships between the hypothesised and represented elements (fig. 8). At any time, the cubical anamorphosis can be digitally verified in the 3D space by offering the possibility of a constrained view that makes the virtual space identifiable. In this way, the user has a full view of their product from within the space. From alternating viewpoints (inside/outside), the researcher can visualise the essential aspects of his analysis/hypothesis before resorting to detailed 3D modelling.

The second synthesis application (E IX) starts from the state of affairs (survey culture). Emblematic for the type of analysis is the interior of the Solimene factory (Vietri sul Mare, 1950-1955), a building chosen as a sample both for the evocative articulation of the interior space, and because it was surveyed by the authors with all sorts of instruments and then digitally reconstructed with information modelling techniques [Rossi 20 I7; 20 I 8; 2019; 2020]. The analysis carried out on the panoramas allows scientific and cultural verifications on the adopted method which is original and innovative for its mathematical foundation. Working hypothesis two photographic giga-panoramas (one external and one internal) captured covering each a field of view of $360^{\circ}$ on the vertical axis and $180^{\circ}$ on the horizontal. The multiple photographic shots captured with the aid of a motorized panoramic head (Gigapan Epic Pro) were superimposed and digitally stitched together using dedicated software (Color Autopano Giga), to generate the panorama in 'equirectangular' projection (fig. 9). As is well known, it is possible to project the observer's eye in the first nodal centre of the camera, allowing him to inspect in an immersive way the inside of an ideal sphere whose radius measures the distance between the nodal centre and the smeared surface of the photographic mosaic.

A similar experience can be had by replacing the spherical surface with a cubical surface (fig. 9) to share the same panorama and thus the graphic information (mathematically, a homeomorphism). The cube/sphere relationship, now developed at the computer level thanks to 
Fig. 8. Final cubical composition of exercise VIII (below) and immersive visualization d'Alesio TAR a 2019/20. Unicampania Department of Engineering (prof. A Rossi).

Fig. 9. Full-field panoramic acquisition of the Solimene ceramics factory. Equirectangular format (top) cubical (bottom) and immersive visualization (middle). Graphic elaboration by Lucas Fabian Olivero.
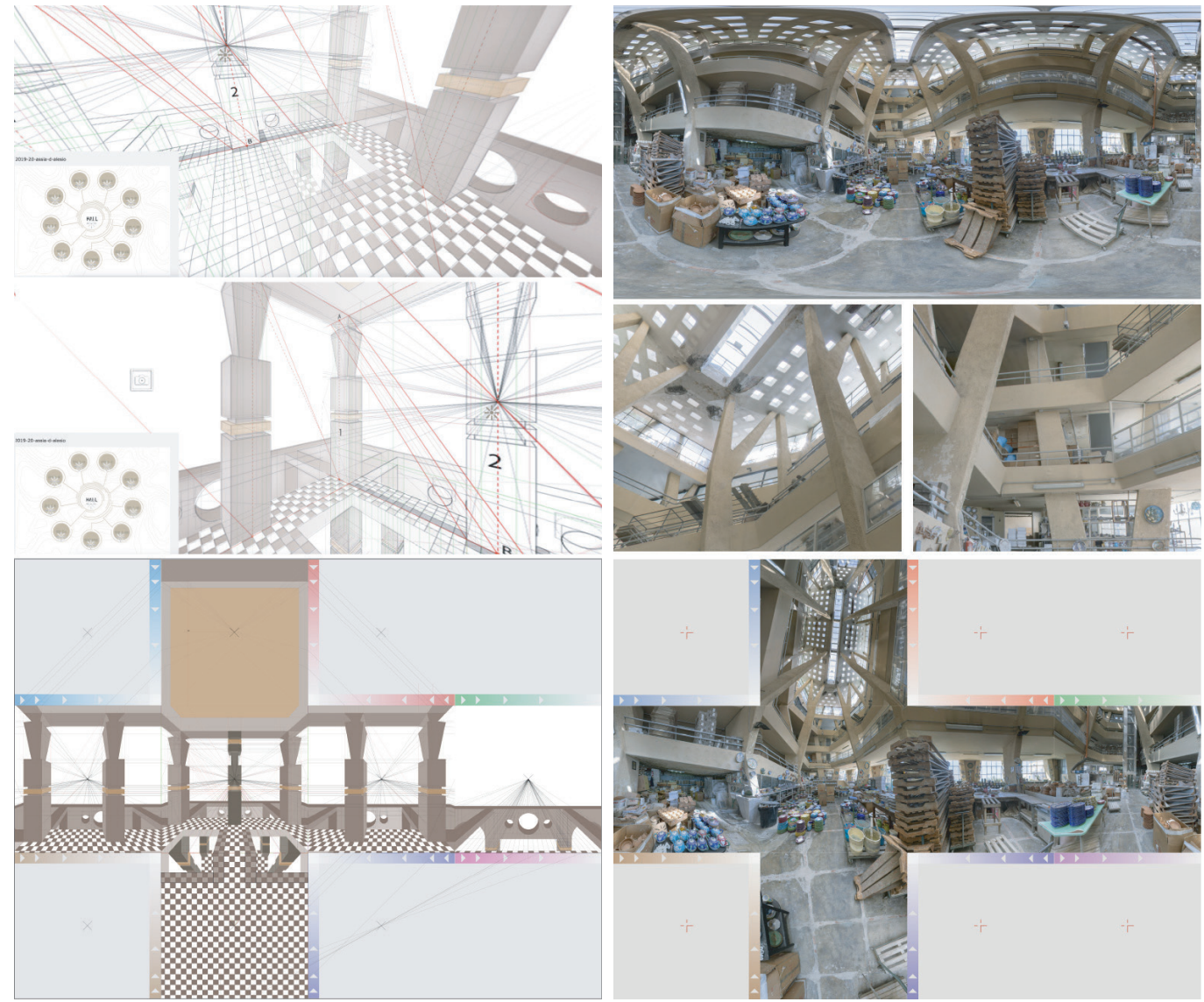

Environmental Mapping, the photographic panorama has been converted into a cubical projection and then transcribed into a vector.

In reading the relationships between architectural elements, the operator tests interpretative hypotheses (fig. I0) but also the mathematical correctness of the interpretations (fig. I I) such as, for example, the more complex construction inherent to geodesics [Araújo 2020, pp. 39-42]. Both synthesis exercises focus on the possibility of recovering the virtual continuity of space-time, to physically experience what is represented. From the knowledge gained through direct contact with a certain aspect of reality, a process of redefining knowledge and concepts ensues. Hybrid models, therefore, offer an alternative opportunity to the analysis of the existing or vice versa to the verification of the project. The immersive mode offers the opportunity to touch the limit between what exists or could exist, between what "can and cannot be done" [Purini I996, p. I5].

\section{Deductions}

The applications discussed in the paper have given us the possibility to verify at the operative critique level the theoretical bases of the cubical perspective that we studied previously. The analysed case studies have allowed us to introduce one of the most interesting aspects of our current research in the field of architectural representation. Immersive fruition of environments constructed in cubical perspective or of environments rendered through its rules has been used as a system to explore, verify and communicate architectural composition exercises (design culture) and interpretation of the built environment exercises (survey culture). Up to date with our times and in alignment with the disciplinary tools and methods we analysed the innovative potential of the hybrid model which combines the originality of the composition schemes) or vice versa the survey drafts) with their digital navigation. Thanks to its scientific 


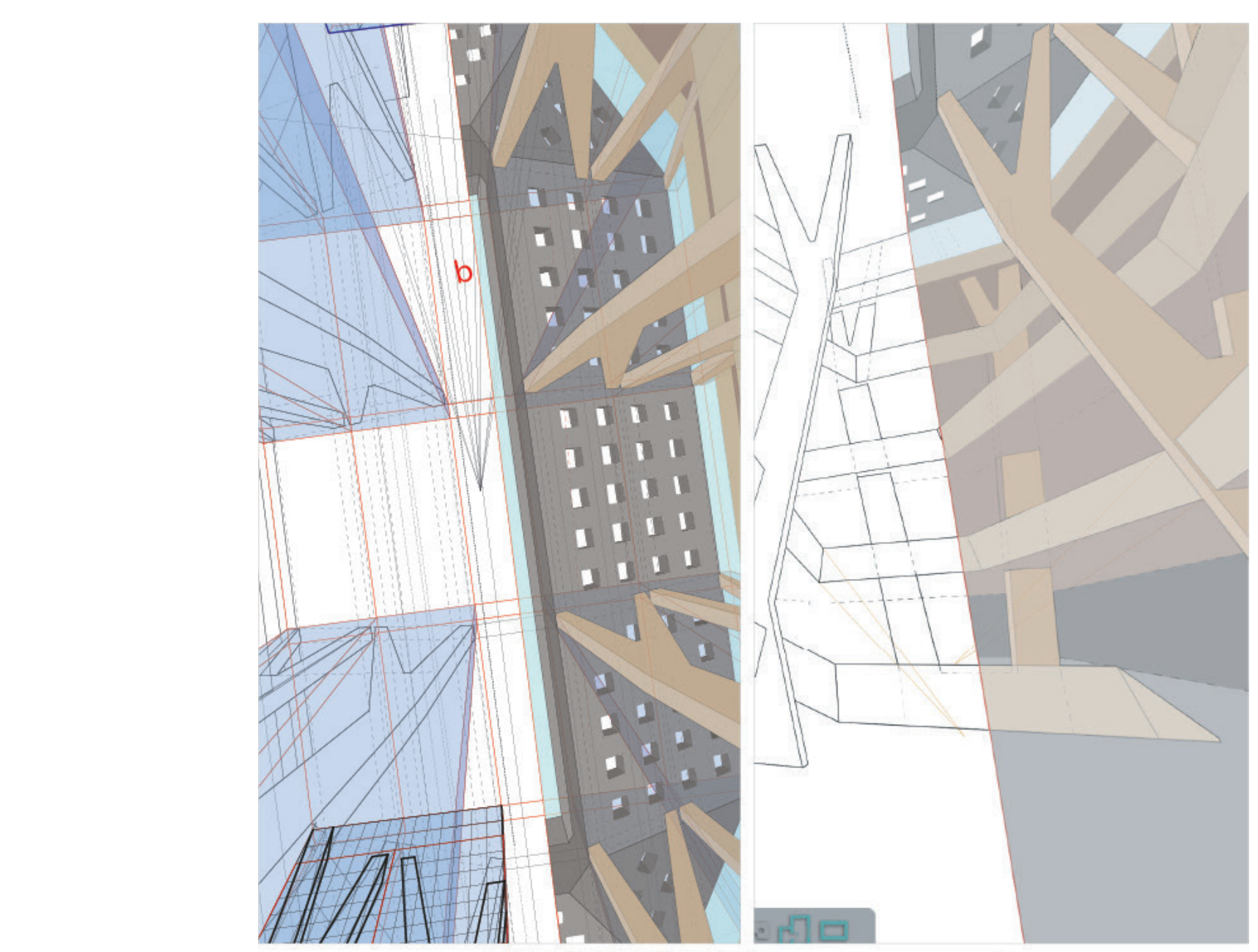

Fig. 10. Synthesis exercise E IX (survey culture). Analysis of compositiona elements, vanishing points and geodesic lines used (below). Immersive

visualization (above)

Graphic elaboration by

Assia D'Alessio, Teresa Di

Palma Caterina Crispino,

Marta Campanile, Maria

Petrillo and Lorenzo

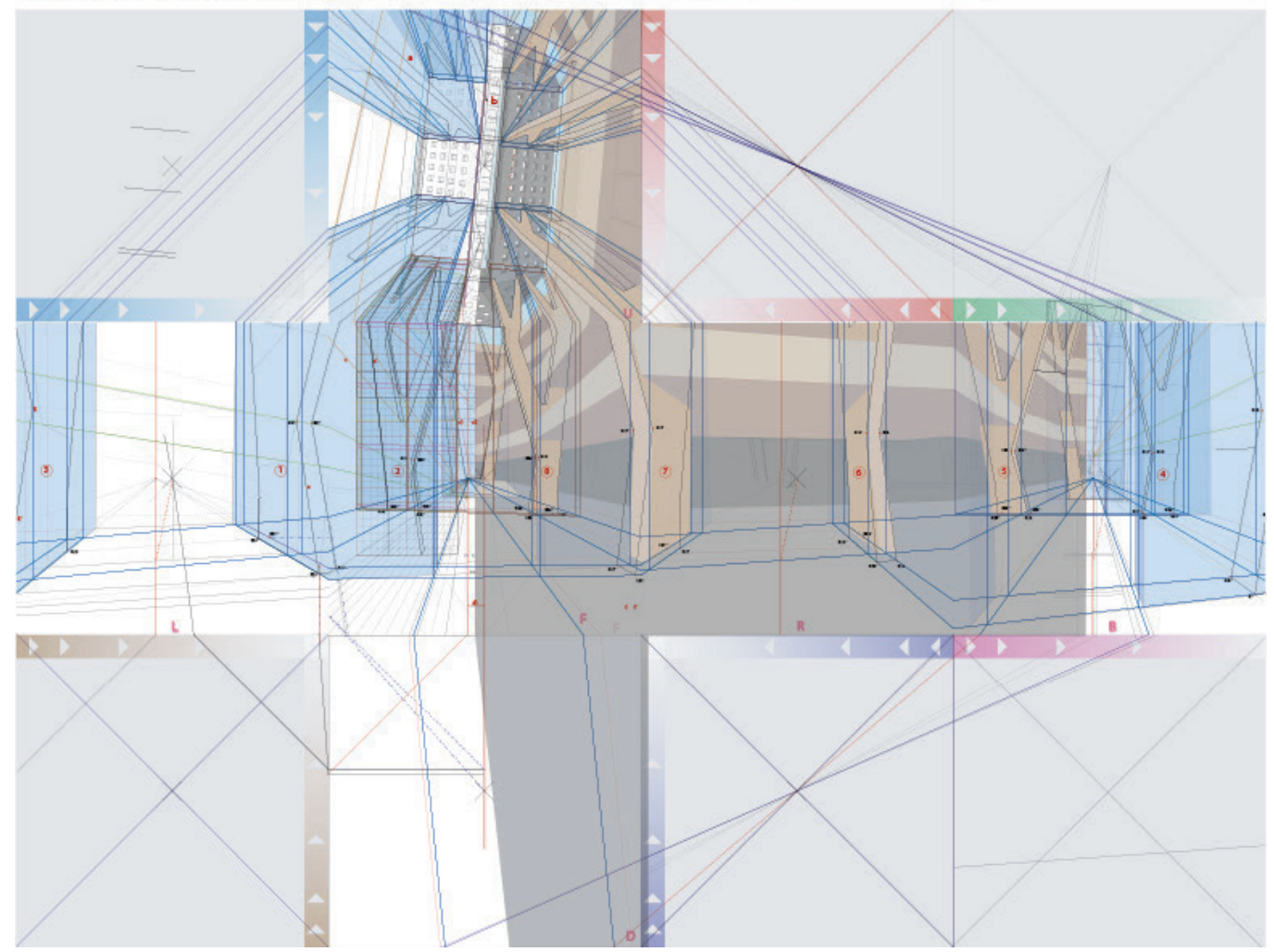



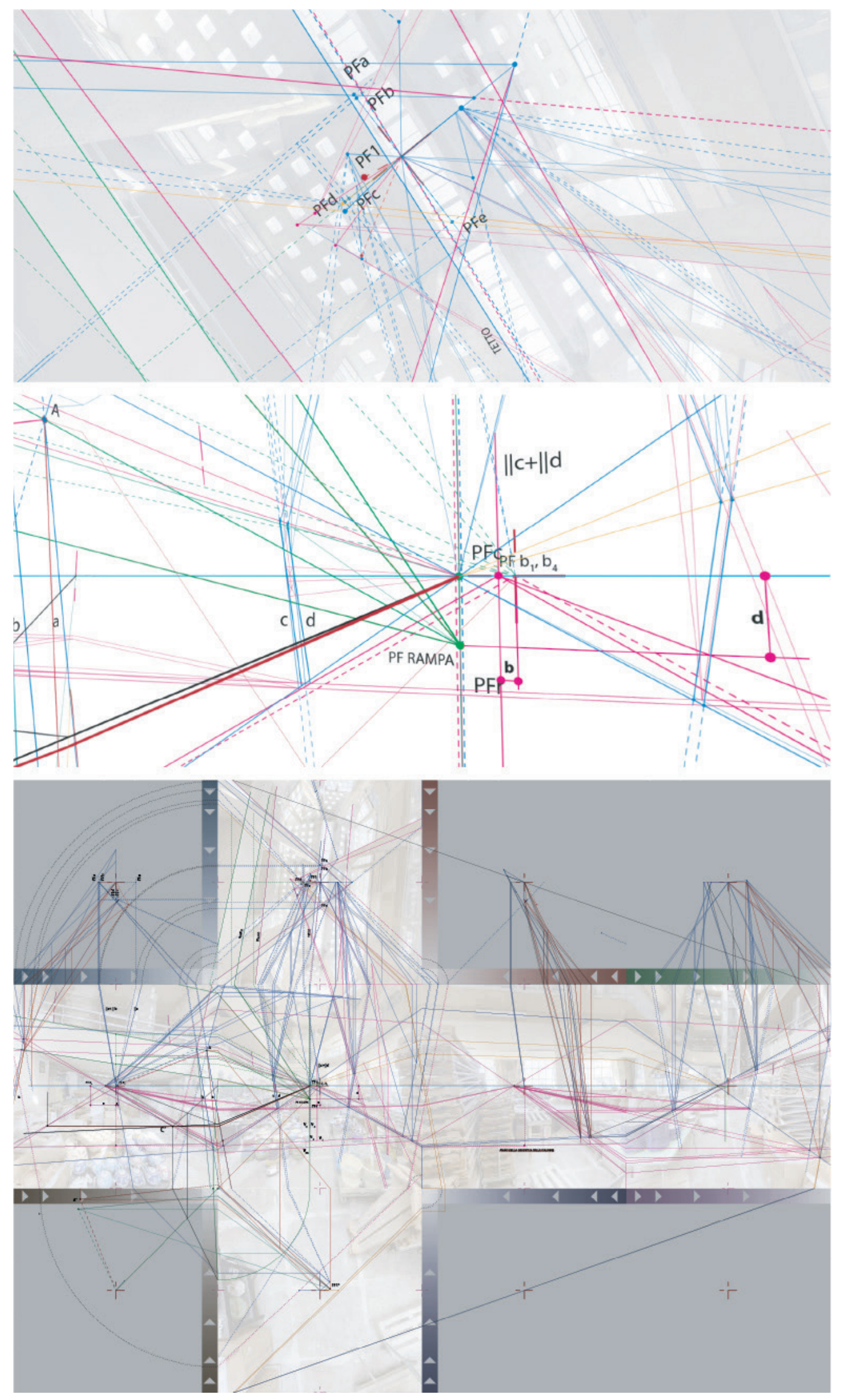

Fig. I I. Synthesis exercise E IX (survey culture) with geodesic lines

starting from average

values (above). Detail

of the mathematical

criteria adopted. Graphic

elaboration by Lucas Fabian Olivero. 
Fig. 12. Synthesis exercise E IX. Immersive readin of geometric relations (above). Restitution of modules in plan and associated sections (below). Graphic elaboration by Assia D'Alessio, Teresa Di Palma, Caterina Crispino, Marta Campanile, Maria Petrillo and Lorenzo Villani.
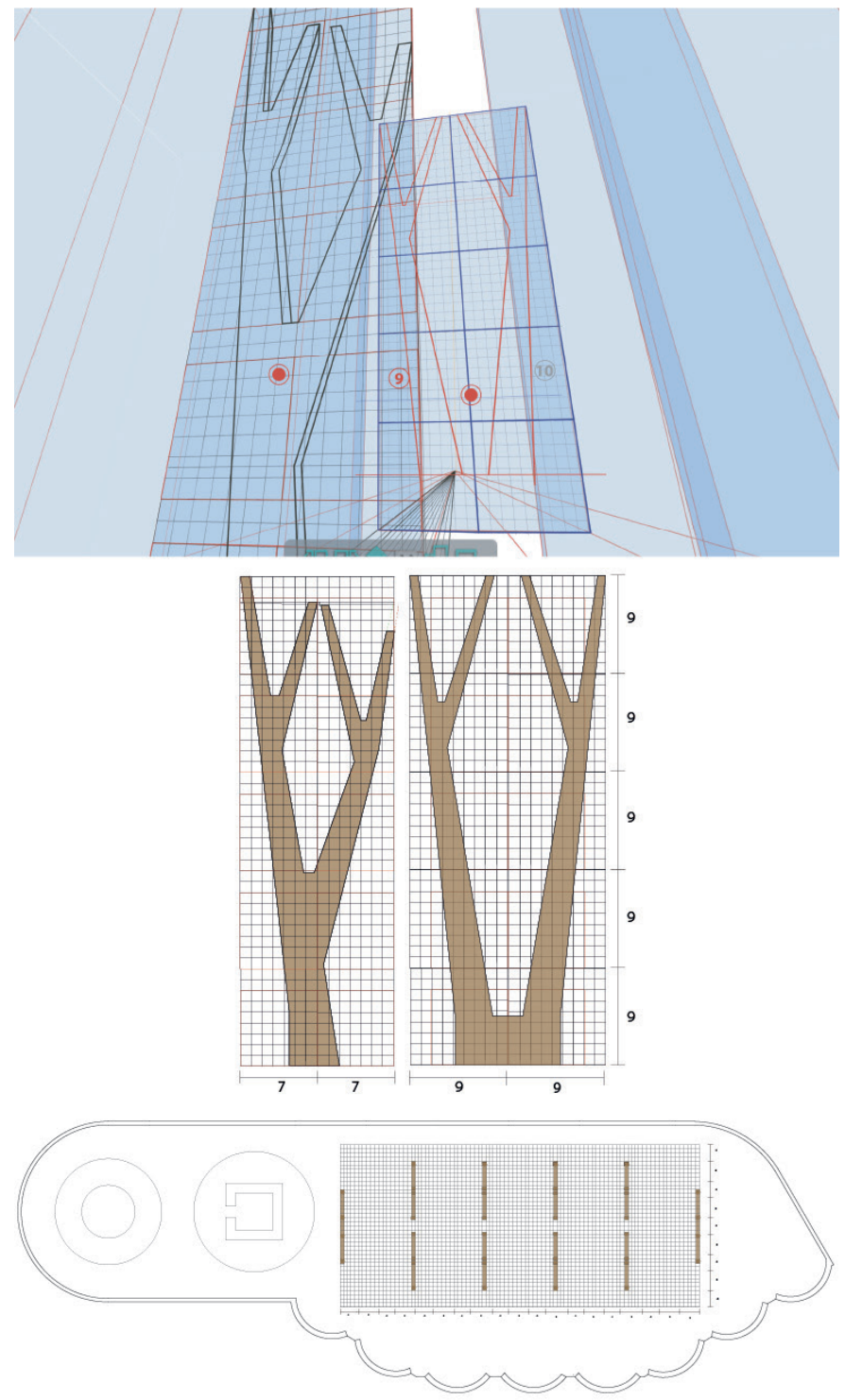

nature, the comparable and verifiable procedure traces a further step ahead in the integration of methods and languages of visual and multimedia communication. The procedure offers the scholar a twofold opportunity: on the one hand, the possibility to exploit the rapidity and immediacy of intuitive cognitive thought, which is made objective by the graphical signs, and, on the other hand, the possibility to take advantage, from the speculative point of view, of the fruition efficacy of immersive techniques that allow the operator to experience digital scenarios.

\section{Results achieved and expected}

The work presented in this paper stimulates firstly a process of representation more than of illustration. By focusing on the idea of representation it emphasizes the uniquely human ability to extract/abstract architectural elements to manipulate interpretations of the built environment with greater awareness (survey culture), or, by reversion, it allows verifying the rhythms of ideal compositions in virtual spaces (design culture).

The procedure which is based on the scientific fundamentals of descriptive geometry allows to integrate the immediacy and intuition of the analytical selection performed in the hand 
drawn sketch with the advantages of illustration and representation deriving from the 3D fruition of the selection of the elements constructed in the plane.

The digital cooperation procedure VR-AR, initially approximately devised for the fruition of the interior of the Solimene factory [Rossi, Olivero 20 I8], is currently based on the domain of a series of scientific or technical solutions, sometimes abbreviated, that allow to mathematically dominate the potential of the graphical signs or plastic elements which shift from the interpretation level to the control of design level.

For the architecture drawing cognoscenti the main open and debated issue concerns the final objectives of the relationships between the use of techniques and their potential to become cognitive levers in the process of design space configuration.

The execution modalities are particularly suited to the purpose because the model can be developed in the plane using traditional tools such as compasses and rulers.

The geometric construct can be digitally navigated and provides a framework within which the observers/users are guided, according to precise criteria, to re-trace the relationships established between non load-bearing and load- bearing elements [Rossi et al. 2020].

Following good experimental practices, the case study explores the possibility of using analogical sketch derivations to probe the multiple variations underlying the framework of relationships between the architectural elements extracted and abstracted from the volumes presented in cubical perspective so that they can be navigated using devices.

By changing the type of sight, the type of perception changes. The graphical virtualizations of the 3D element are aimed at guiding, within the conceptual and application template, towards the formation of what Martin Heidegger (the german philosopher, considered the greatest exponent of ontological existentialism) has called "new images of the world" [Heidegger 1954]. Walking in a re-presented or refounded space, when it does not exhaust itself tautologically in an autistic virtuality, makes the experience fluid and immediate, helps to become familiar with the problem to be analyzed and solved, guides us to reconfigure the relationship between observer and object.

In navigable models, visual sensation correlates with visual perception. The union initiates an intellectual process that actively participates in the rationalization of thought and therefore in its re-foundation. The more the system is adaptable to immersive navigation, the more the contents are shaped, oriented by the user's cultural background, by his desires and expectations and recorded with extreme precision and speed with the technological systems available.

Despite the fixed position of the users at the centre of the cubical space, they are free to observe the complete field to validate factors that can contribute to defining the quality of what was acquired and classified.

This is the procedure that, integrating and supporting the previous ones, that enables us to delve into the most interesting aspects of our current research in the field of architectural representation.

The advantages include the possibility to: contextualize the value of the hand-drawn sketches; rationalize in the plane of the cubical perspectives the configurations of the architectural elements; automatically develop, using the same 2D data (a few primitives, visual or graphical elements), a simplified 3D space not as elaborate as those usually used to model volumes and surfaces for other purposes; validate the workflows required by the automated processes used for monitoring spherical panoramas converted into cubical shape to correct errors deriving from the evident discontinuities of the 3D simulations and, last but not least, to stimulate the holistic study on the configured space.

\section{Acknowledgements}

L.F. Olivero gained his PhD in 'Environment, Design and Innovation', in March 202I. His three year course, 2017-2020 was fully funded by the University of Campania 'Luigi Vanvitelli', Italy. The title of the Thesis is "Hybrid Immersive Models from cubical perspective drawings". The supervisor of the thesis was PhD A. Rossi, full professor at the Department of Engineering, University of Campania 'Luigi Vanvitelli' (Italy). The international supervisor was PhD A.B. Araújo, assistant professor at the Universidade Aberta (Portugal). From March 202 I on, L.F. Olivero is being funded by FCT for a second PhD in Digital Media Art at the Universidade Aberta and Universidade do Algarve, Portugal. 


\section{References}

Araújo A.B. (2018a). Ruler, compass, and nail: Constructing a total spherical perspective. In Journal of Mathematics and the Arts, n. 12 (2-3), pp. $144-169$.

Araújo A.B. (20।8b). Drawing Equirectangular VR Panoramas with Ruler, Compass, and Protractor. In Journal of Science and Technology of the Arts, n. 10 (1), pp. I5-27.

Araújo A.B., Olivero L.F., Rossi A. (2019). Boxing the Visual Sphere:Towards a systematic solution of the cubical perspective. In Belardi P. (Ed.). REFLECTIONS the Art of Drawing | the Drawing of Art, pp. 33-40.

Araújo A.B., Olivero L.F., Rossi A. (2020). A Descriptive Geometry Construction of VR panoramas in Cubical Spherical Perspective. In Diségno, n. 6, pp. 35-46.

Carbone E. (2017). An ancient space-time revisited. Computer models for documentation and optimization of the Environmental Heritage. In Rossi A. (a cura di). Immersive high resoluttion photographs for cultural heritage. Drawing/Disegno. vol. 2, pp. |03- | | 5. Padova: libreriauniversitaria edizioni.it.

Dimitrijević A.M., Lambers M., Rančić D. (2016). Comparison of shperical cube map projections used in planet-sized terrain rendering. In Facta Universitatis, Series: Mathematics and Informatics, n. 3 I (2), pp. 259-297.

Donnelly P. (2007). Video game play using panoramically-composited depth-mapped cube mapping (United States Patent No. US7256779B2)

Gaio Plinio Secondo (77-78). Storia naturale, V. Mineralogia e storia dell'arte. Libri 33-37. Tr. it. Corso A., Mugellesi R., Rosati G. Torino: Einaudi 1988.

Heidegger M. (1954). Che cosa significa pensare? Milano: SugarCo Edizioni 1996

Olivero L.F., Araújo A.B., Rossi A. (2020). Applications of Cubical Perspective in Architecture, Engineering and Product Design In Fátima Silva M. et al. (Eds.), 4. Seminário Internacional de Arquitectura e Matemática, Universidade Lusíada, vol. I, pp. 63-86. Lusíada: Universidade Lusíada.

Olivero L.F., Rossi A., Barba S. (2019). A codification of cubical projection for the generation of immersive models. In Diségno, n. 4, pp. 53-63.

Olivero L.F., Sucurado B. (2019). Analogical immersion: Discovering spherical sketches between subjectivity and objectivity. In ESTOA. Revista de la Facultad de Arquitectura y Urbanismo de la Universidad de Cuenca, n. 8( I 6), pp. 47-59.

Purini F. (1996). Una lezione sul disegno (First Edition edition). Roma: Gangemi.

Rossi A. (2014). Introduzione al disegno informatico per l'architettura e l'ingegneria edile. Torre del Greco (NA): Edizioni Scientifiche e Artistiche.

Rossi A. (20 I5). II Vero si prolunga nel Verosimile. In Bartoli M.T., Lusoli M. (Eds.). Le teorie, le tecniche, i repertori figurativi nella prospettiva d'architettura tra il '400 e il '700: Dall'acquisizione alla lettura del dato. Firenze: University Press, pp. $335-346$.

Rossi A. (20 17). The Façade of Paolo Soleri's Solimene Factory. In Nexus Network Journal, n. 19(2), pp. 503-520.

Rossi A. (20 18). El analisis de la forma en el diseno arquitectonico: Desde el projecto a la ejecucion/The analysis of the form in the architectural design: from the project to the execution Between survey and design: the work in progress variations. In EGA. Revista de expresión gráfica arquitectónica, n. 22(32).

Rossi A. (2019). BIM - OGGI - ITALIA. Drawing/Disegno. vol. 3. Padova: libreriauniversitaria edizioni.it.

Rossi A., Olivero L.F. (20I8). Immersive models from analogical sketches applied to Solimene's Factory. In EGRAFIA. Argentina: UniRío Editora.

Rossi A., Olivero L.F., Araújo A.B. (2020). For Representation, a New Reality: Hybrid Immersive Models. In Magnaghi-Delfino P. (Ed.). Faces of Geometry 2020. Cham: Springer International Publishing.

Rossi A., Palmieri U. (2020). Modelling Based on a Certified Level of Accuracy: The Case of the Solimene Façade. In Nexus Network Journal, n. 22(3), pp. 615-630.

\section{Authors}

Adriana Rossi, Università degli studi della Campania “Luigi Vanvitelli”, adriana.rossi@unicampania.it Lucas Fabian Olivero, Università degli studi della Campania “Luigi Vanvitelli”, lucasfabian.olivero@unicampania.it António Bandeira Araújo, Universidade Aberta, antonio.araujo@uab.pt

To cite this chapter. Rossi Adriana, Olivero Lucas Fabian, Bandeira Araújo António (2021). Spazi digitali e modelli immersivi: applicazioni di prospettiva cubica/Digital Environments and Immersive Models: Applications of Cubical Perspective. In Arena A.,Arena M. Mediati D. Raffa P. (a cura di). Connettere Un disegno per annodare e tessere Lingugori Distanze Tecnologie. Atti del $42^{\circ}$ Convegno Internazionale dei Docenti delle Discipline della Rappresentazion Representation Disciplines Teachers. Milano: FrancoAngeli, pp. 262 I-2642. 